\title{
Hidden principles of improvisation
}

\author{
Jacques Coursil \\ Sophienstrasse 1, 52070 Aachen, Germany \\ e-mail: jacques@coursil.com
}

\begin{abstract}
On the basis of the principle of non-premeditation of speech, we argue that the synchronicity of hearing shared by everybody present is incompatible with a division of time between a sender and a receiver of a message. The act of speech brings the participants together in a single moment of perception called a synchronous point. Both the act of speech and music do not appear through time; rather, speech and music create time. The present time of our casual experience always contains a part of radical novelty, probable a posteriori, yet never predicted. Despite our capacity to predict many things and repeat procedures, in the advent of a given moment, the present will always show its uniqueness. Thus, improvisation is based on two principles of uncertainty: the non-premeditated occurrence of speech and the non-predicted part of present time.
\end{abstract}

Keywords: creativity, musical semiotics, non-premeditation of speech, semiotics of novelty, specious present, synchronous point

Improvisation is a practice. As such, it poses a semiotic question of a cultural and technical nature. The practice of improvisation covers a large variety of arts. We will focus on music, taking spoken language as a theoretical horizon, and start with a basic disposition of language use.

\section{Improvised music and the principle of non-premeditation of speech}

A spoken chain, or an improvised line, however long it may be, has a beginning and an end. This apparently banal observation is in reality not trivial because a remarkable property is associated with each of the boundaries: initial and final. The initial boundary, 
on which we will concentrate here, ${ }^{1}$ is associated with the fact that, in common speech or improvised music, the chain of words or sounds is not premeditated by the speaker or the player. It arrives without his knowledge, without warning. Thus, in the act of speaking, the chain is not mentally constructed before it is uttered; the same holds for improvised music.

The non-premeditation of common speech is a basic principle in human semiotic behaviour and constitutes as such an unconscious foundation for all acts of improvisation. In other words, improvisation is rooted, beyond the realm of will, in an anthropological disposition. In a common dialogue, does the speaker choose his words before uttering them? Does he control the elements of the spoken chain and their relationships? Does he compose the chain before saying it out loud? Clearly, the answer is "no". The chain is neither premeditated nor preassembled by the speaker. Put differently, we have to admit the simple fact that speech is not a deliberate construction, but escapes our control. If we pay close attention, we observe that sentences emerge spontaneously, in an impromptu fashion, without any voluntary or reasoned combinatorial work: sentences turn out to be assembled without having been consciously assembled. The elements of the uttered chain are not announced. They come without our awareness. In other words, the act of speaking is not a construction, but is surging forth.

The principle of non-premeditation is a basic concept of language use. ${ }^{2}$ It constitutes a powerful challenge to the common-sense conception of a subject who first thinks and then expresses his ideas through well-chosen words. Thus, the act of speaking, which is the sign of individual freedom, power and knowledge, is oddly placed outside his conscious control. This may sound paradoxical. Let us look at a few cases.

Singing a song as opposed to telling a story. Singing a song, or reciting a poem, presupposes that words have been memorized whereas telling a story does not presuppose either texts or words in advance. Consequently, I can't recite a poem or sing

1 The second property applies to the end of any act of speech. It is associated with the fact that the chain of signs is not conserved in memory by the participants of the dialogue. Indeed, just a few exchanges suffice for the participants to have totally forgotten the precise terms of the preceding chain and its form. Thus in a dialogue, the chain of words appears in order to eventually disappear. A simple experiment will make this clear: the fact that I have followed a conversation closely does not presuppose that I have learned it by heart. Not that I could not have memorized it, but in everyday practice memorization is not useful. The same holds true when one is listening to an improvised music piece for the first time. This property of nonconservation of sentences or musical lines shows that the memory principle of language and improvised music does not operate based on conservation. (See also Coursil 2000, 2015.)

2 "[... or,] de tous les actes que l'on pourrait mettre en parallèle, l'acte linguistique, si je puis le nommer ainsi, [a ce caractère dêtre] le moins réfléchi, le moins prémédité, en même temps que le plus impersonnel de tous" - "[...] among all acts comparable, the linguistic act, if I can call it this way, has the characteristic of being the least preconceived, the least premeditated, and at the same time, the most impersonal of all" (Saussure, ELG: 150; my translation, J. C.). 
a song if I don't know the words or the lyrics. But this limitation does not apply to telling a story. It is awkward to say (although the sentence is syntactically and semantically correct) - Sorry, I can't tell this story because I don't know the words. In everyday speech of this sort, words are not premeditated. Consequently, the following request is a contradictio in adjecto: Please tell me the story but don't leave out a single word. A story to be told is not attached to any particular words or chains of words. For a known story, there is an infinity of possible narratives. Because of this lexical and syntactic unpreparedness of speech, the speaker is de facto a creator. When characterizing common speech, Herder wrote the famous and obscure sentence, "To speak is to make poetry". This everyday poetics is not an art but a basic and compulsory disposition of language use. In the social protocol of common dialogue, the premeditation of speech is forbidden: to recite is not accepted as a form of talking, as common speech has to be creative and new as a basic feature. This also holds for (truly) improvised music.

Witticism. Let us take witticism as an example of language creativity. Insults burst out and have their intended effect when they are new and appropriate. Of course, it is possible to have a catalogue of ready-made insults in reserve, but the difficulty of selecting the right one at the right moment might ruin the maneuver. In order to insult someone with a witticism, we must be alert and eloquent. Eloquence is an artistic state, which confirms, if confirmation is needed, that one can be aware of the lack of premeditation, but cannot be exempted from it. Like any good improvisation, a witticism worthy of its name must be spontaneous, original and timely, for preparing a witticism ahead of time in order to bring it out at the right moment contradicts the principle of witticism itself.

In the light of statistical observations, we may conclude that spoken language is astonishingly repetitive and habit-driven, strongly ritualized and full of formulaic expressions. In short, creativity in language is so rare that it cannot be a linguistic principle. In the same vein, one can ask whether there is, among all the clichés, such a thing as an improvised piece of music? Yet these quantitative observations leave the principle of nonpremeditation intact, as can easily be shown. For instance, we know why it is so difficult to speak in public without preparation, so hard to say what needs to be said using the right words. In this familiar exercise of eloquence, the speaker notices that language is not a docile instrument of expression, but an unpredictable and reluctant reality.

Unquestionably, before we begin to talk, it is good to know what we are talking about; but the exact arrangement of the words stays beyond our control. In other words, the property of non-premeditation precludes associating the speaker with a prior, constructive and conscious lexical, syntactic or stylistic intention. The words in a sentence or the notes in an improvised melody are not chosen one after another by the subject. In fact, no conscious agency controls the advent of the spoken or musical chain in the form it finally takes. 


\section{Synchronous point}

The participants of a dialogue hear the chain being produced at the same time, including the speaker, since he/she has no prior knowledge of it. The participants catch the chain's advent simultaneously and not one after another. This is the reason why the following dialogical situations are awkward: She heard Paul after he spoke or Paul said it before she heard it or She heard what Paul said before Alfred did. The speech imposes itself to everyone present simultaneously. Thus from the simplest utterance to the subtlest witticism, the act of speech unites the participants in a single moment of pragmatic perception called a synchronous point.

In a dialogue, none of the participants, not even the speaker, has a prior knowledge of the linguistic elements coming up. Here again, the spoken chain, like the improvised melodic line, only comes into existence when put into action: before its advent, it has no ontological status.

This synchronicity of hearing shared by everybody present is incompatible with a division of time between a sender and a receiver of a message as suggested metaphorically by the classic schema of communication. This linear representation induces an illusory lapse of time between emission of the utterance (encoding) and its reception (decoding), which has no pragmatic reality. The factual status of the synchronous point deconstructs this widely spread imaginary representation.

In improvised music, in like fashion, the performer and the audience hear the sounds at the same time. Unless he/she plays clichés, he/she does not have any head start regarding forms, notes or timbres, even if the tonalities and the modulations are given in advance. In other words, the performer is also, without a doubt, a listener. The synchronous point constitutes a primary feature of socialization, as it brings together all the participants in a single "intuition of the instant", as Bachelard (1932) wrote for the title of one of his books on time.

The analogy between improvisation and linguistic theory is not simply formal since language use is a constitutive feature of any human expression.

\section{The art of improvisation}

The art of improvising is rooted in a characteristic property of natural language use. However, though necessary, non-premeditation is not a sufficient criterion for defining improvisation. Let us take a couple of examples to highlight the difference of scope between non-premeditation and improvisation: Please, tell us a story - as opposed to - Please improvise (invent on the spot) a story. Indeed, improvising a story takes more than the unpremeditated flow of significant signs that characterizes storytelling; it is an art. In fact, anybody can recite a poem or sing a song, but to improvise a poem 
or a song presupposes a substantial practice. The following examples correspond to these two different requests: Recite a poem - as opposed to - improvise a poem; Sing a song - as opposed to - improvise a song. For improvisation, art is required.

In music, there is a strong difference between an improvisation and a performance. First, in the act of improvisation, there is in principle nothing to be performed (prewritten, preconceived and rehearsed forms); in improvisation, the player is somehow overrun by his own playing whereas performance implies full control of the forms, either through reading or memorization of a score. Second, improvisation cannot be reduced to the display of instrumental virtuosity and agility. We should also keep in mind that expressionism would be a misleading question in improvisation because it supposes the old myth of interiority; i.e., a-deep-inside-in-my-heart expressed to an outside world. ${ }^{3}$

As a professional practice, improvisation is obviously a premeditated action but, curiously enough, its form and content are not. Thus we will say that it is a premeditated act of non-premeditation, or in other words, an ago-antagonistic disposition.

\section{Improvisation and systems of musical values}

It is impossible to generalize any further on improvisation. The concept varies with the intonation tables specific to particular cultures. Moreover, modal, tonal, atonal or free forms of improvisation are distinct practices. Improvising melody lines or songs is to be distinguished from improvising on the basis of harmonic changes, which is different from improvising recitative forms, where the player in modal music takes the position of the storyteller, and so forth. This holds for improvisation of timbres in contemporary improvised music.

Music is not an art of approximation, even regarding the most open forms. ${ }^{4}$ Technically speaking, improvisers deal with intervals (minimally: octave, fifth, fourth...). They do not manipulate units (notes), but intervals, which are differential values. Then in tonal or modal music, improvised sequences of intervals emerge from a domain of expected values. They are supposed to be original paths of intervals formed in a predefined and shared structure.

Each social being has interiorized semiotic systems, which are constitutive of all cultures: music, language, natural integers, etc. We hear music through a pre-acquired system of harmonic and rhythmic values. In a similar fashion, we understand speech because we have interiorized a grammar.

See Wittgenstein 1953.

4 Music in all of its forms, even without wanting, always falls under the law of numbers. 
Although language and improvised music share fundamental principles, they are nevertheless two autonomous systems. For example, as opposed to language, music is a system of values without signs. We also need to consider that an act of speech, as opposed to music, is necessarily a solo act (usually, in a dialogue only one participant speaks at a time). Music builds simultaneities of voices, but speech is always an act for a single person; unisons and choirs belong to ritual and to theatrical practices only. The simultaneity of singing voices leads to harmony, but the simultaneity of talking voices leads to linguistic disaster.

\section{Improvisation as time value - Musikalische Momente}

Instances of improvisation are both event and trace, or, as Schubert put it, Musikalische Momente (musical moments). ${ }^{5}$ A moment of improvised music is a time value in our live. The understanding of improvisation as time value, as presence, rather than as a purely aesthetic form, puts our common-sense representation of time into question.

In Western cultures, the standard representation of time is linear. Time is conceived of as a horizontally oriented vector separating past and future by an immaterial point, the present. This familiar image of a time line is a strong cultural standard and has resisted all sorts of criticisms, scientific or philosophical, recent or ancient. Under such a linear conception, the so-called fluidity or "viscosity" of time, as Bachelard (1932) called it, does not allow any room for the present, for it disappears in the very moment of its apparition. The present, having no measurable length on this representation, has no duration either. Consequently, between the past and the future, there is no time left for the present time.

In order to question this commonplace linear conception, which is incompatible with the understanding of improvisation as time value, let us consider the observation that it is, indeed, now that I am thinking of yesterday, of tomorrow, next year or of the past centuries. Events are past or future only in the present as acts of thought. Yesterday and tomorrow occur today. Only present time allows my conceiving of past and future. In this perspective, the present is no longer a furtive point on a line but a subjective experience during which past and future are maintained or transformed. This anamnesis supposes a duration. ${ }^{6}$ Then, contradicting common sense, we will say that past and future, as they suppose an act of thought, always happen in present time.

Musikalische Momente, six last piano sonatas by Franz Schubert.

Cf. Ricoeur 1963; Husserl 1991. 
The advent of the present coincides with the deconstruction of a previous present. It is an event, "un événement rupture," according to Foucault (1966) which triggers the advent of a new value disposition, a new situation.

Music and speech happen in this sort of time, which proceeds by sequences of transformations; as such, it is a necessary feature of improvisation. But, as acts of speech, music does not appear through time; rather, music creates time. In other words, temporality is not a given framework for speech or for music: time has to happen, and speech and music make it happen.

\section{Improvisation and the novelty of the present}

The present in our common experience always contains a part of radical novelty, a genuinely new part that could not have been declared beforehand in a future tense. ${ }^{7}$ We can predict many things, we can repeat procedures, but the present will always happen in its uniqueness.

The mix of a predictable order with an intrinsic novelty of time characterizes the present as an unstable space. What is happening now contains a part that has never been previously declared in the future tense in any past discourse. In other words, this part of present time was neither predicted nor declared. It would be hard to conceive of a moment in social life that had been entirely described in a statement in future tense before it happens. We might have to change our habit of thinking in linear terms, implying the idea that the future comes after the present, as yesterday's future can be today's past.

\section{Conclusion}

Musikalische Momente, moments of improvised music, are thus based on two principles of uncertainty: the non-premeditated occurrence of speech and the non-predicted part of present time. It is in this unstable structure that the subject thinks, speaks and improvises.

Improvisation falls clearly within the realm of the unconscious. This space of music values is silent in memory and the improvised line is non-premeditated. Clearly, one can learn choruses of Charlie Parker by heart and transcribe them on paper, as musicians do, and as I did, but when it comes to improvisation, this does not give you the slightest clue or hint; in improvisation, one has to invent an event, that is to say, create the advent of a present. This is what is meant by improvisation as time value.

7 Cf. Duhem 2003. 
An improviser is a musician who has opted for the field of non-premeditation of events. The more improvisation gets away from this characteristic, as in ritualized practices or playing clichés, the less it justifies its name. ${ }^{8}$

\section{References}

Bachelard, Gaston 1932. L'Intuition de l'instant. Paris: Gonthier.

Coursil, Jacques 2000. La fonction muette du langage. Point à Pitre: Ibis Rouge.

- 2015. Valeurs pures, le programme systémique de F. de Saussure. Limoges: Lambert-Lucas.

Duhem, Pierre 2003. Sauver les apparences: Essai sur la notion de théorie physique de Platon à

Galilée. Paris: Vrin.

Foucault, Michel 1966. Les mots et les choses. Paris: Gallimard.

Husserl, Edmund 1991. Leçons pour une phénoménologie de la conscience intime du temps. Paris: PUF.

Ricoeur, Paul 1963. Temps et récit. Paris: Seuil.

Saussure, Ferdinand de 2002. Écrits de linguistique générale. (Bouquet, Simon; Engler, Rudolf, eds.) Paris: Gallimard. [ELG]

Wittgenstein, Ludwig 1953. Philosophical Investigations. (Anscombe, Gertrude E. M., trans.)

Oxford: Blackwell.

\section{Скрытые основы импровизации}

Лежащий в основе нашей статьи принцип неподготовленности речи утверждает, что синхронность слушания участников речевого акта несовместима с делимостью времени между отправителем и получателем. Речевой акт собирает участников в одном и том же моменте перцепции, которую мы называем точка синхронии. Как речевой акт, так и музыка появляются не во времени, а скорее сами создают время. Настоящее повседневного опыта содержит всегда часть радикального новшества, возможное $a$ posteriori, которое никогда не предсказывалось. Несмотря на свою способность многое предсказывать и повторять, настоящее в момент своего наступления всегда показывает свою уникальность. Таким образом, импровизация основывается на двух принципах неопределенности: неподготовленность речи и непредсказуемая часть настоящего.

\section{Improvisatsiooni varjatud alused}

Kõne ettevalmistamatuse printsiip, millest lähtume, võimaldab väita, et kõnes osalejate kuulmise sünkroonsus on kokkusobimatu teate saatja ja vastuvõtja vahelise aja jagatavusega. Kõneakt toob osalejad kokku samal tajumomendil, mida nimetame sünkroonseks punktiks. Nii kõneakt kui ka muusika mitte ei ilmu aja kaudu, vaid pigem loovad aja. Igapäevase kogemuse olevik

8 An earlier version of this essay has been published in: Zorn, John (ed.) 2008. Arcana III: Musicians on Music. New York: Hips Road, 58-65. 


\section{Jacques Coursil}

sisaldab alati osalt radikaalset uudsust, võimalikku a posteriori, mida ometi pole kunagi ette ennustatud. Vaatamata meie võimele paljut ennustada ja korrata, näitab olevik antud momendi saabumisel alati oma unikaalsust. Seega põhineb improvisatsioon kahel määramatuse printsiibil: kõne ettevalmistamatusel ja oleviku ennustamatul osal. 